\title{
Importance of Selective Food During Pregnancy
}

\author{
PD Gupta* \\ Former, Director Grade Scientist, Centre for Cellular and Molecular Biology, India
}

Submission: May 13, 2019 ; Published: June 21, 2019

*Corresponding author: PD Gupta, Former, Director Grade Scientist, Centre for Cellular and Molecular Biology, India

\begin{abstract}
For cell proliferation and division cell requires nourishment. After fertilisation of oocyte, it draws nourishment from the surroundings in Fallopian tube and from the uterine cavity, but after implantation mother supplies nourishment through placenta. We proposed 3 reasons for the importance of selective foods for healthy pregnancy and child birth. Recent researches have established the role of gut, placenta and uterine microbiota in healthy pregnancy and development of child's immune system. The quality of microbiota depends on the type of food is consumed.

The zygote, formed by the fertilisation of egg cell with that of sperm cell, grows and divided rapidly. During this period it draws its nutritional requirements from the fluid contents of the Fallopian tube and the uterine cavity. The fluid contents of the uterine cavity cannot cope up the nutritional requirement of the growing embryo for long. Therefore, finally the growing cell mass makes connection with the uterine wall through an extended tube, the placenta [1]. For this newly formed structure the embryonic cell mass invest $90 \%$ share whereas mother invests only $10 \%$ cells from the uterus lining. This investment is rational since this is life support system for the fetus. During pregnancy a woman's body undergoes various normal physiological and structural changes. These changes assist metabolism of developing embryo and formation of placenta is one of those. The product of metabolism of the nutrients, which a pregnant woman takes during pregnancy passes through the placenta, plays a prime role in well being of that embryo not only during the period of pregnancy but even after delivery and throughout his/her life [2].
\end{abstract}

\section{Introduction}

Due to the fact that fast growing embryo requires extra energy (350-500 calories) over the maintenance of mother's body each day during the 2nd and 3rd trimesters. In addition to this, docosahexaenoic acid (DHA), iron, iodine, calcium, folic acid, and vitamin D are also required [3]. A diet that lacks key nutrients may negatively affect the baby's development. It will also make it a lot easier to lose the pregnancy weight after baby's birth. Pregnant women's omega-3 fatty acids requirements are high especially the long-chain omega-3 fatty acids DHA and EPA, and they are not getting enough omega-3 from their diet [4].

The reproductive performance and its outcome of the female depends on the quality of the uterus, "The Maternal Soil"; earlier we have described types of healthy diets which not only keeps uterus healthy but also influence on mental and physical health of the pregnant woman. The uterine environment generally does not change the genetics of the developing embryo, however, recent experiments have shown that its environment provides the quality of life for the developing embryo and therefore it influence phenotypic characters of the offspring [4].

Selection of Food During Pregnancy is Important for the Reasons: Namely

\section{For a healthy pregnancy and child birth}

The mother's diet needs to be balanced and nutritious. Since the need of calorie and nutrient are increased, it is very important that during pregnancy it is better to choose nutrientdense, fiber rich healthy foods.

\section{The composition of microbiota}

the ratio between beneficial and pathogenic microbiota very much depends on the diet. If the balance between the populations is disturbed, it may cause serious illness. In recent study it is shown that composition of gut microbiota changes in pregnant women, and the changed microbial environment needs changed diet to keep proper balance between beneficial and harmful bacteria.

\section{Slower actions of digestive system}

In general body muscles are relaxed during pregnancy due to higher levels of the hormone Progestrone, this results in slow intestinal movements.

\section{Legumes and Grains (see for details, ref., [4])}

This group of food includes lentils, peas, beans, chickpeas, soybeans and peanuts. Legumes are excellent plant-based sources of fiber, protein, iron, folate (B9) and calcium, all of which the body needs more of during pregnancy. Folate is one of the B-vitamins (B9). Most pregnant women are not consuming nearly enough folate; they should consume more legumes to avoid increased risk of neural tube defects and low birth weight. Insufficient folate intake may also cause the child to be more prone to infections and disease later in life. Some verities of 
legumes also contain iron, magnesium and potassium in addition to fiber. As opposed to refined grains, whole grains are packed with fiber, vitamins and contain a fair amount of protein, which is important during pregnancy.

Dark Coloured Fruits and Green Vegetables (see for details, ref. [4])

Dark coloured fruits and green vegetables contain many of the nutrients that pregnant women need. These include fiber, vitamins $\mathrm{C}, \mathrm{K}$ and $\mathrm{A}$, calcium, Sweet potatoes are an excellent source of beta-carotene - a plant compound that is converted into vitamin A in the Furthermore, sweet potatoes contain fiber, which may increase fullness, reduce blood sugar spikes and improve digestive health and mobility.

\section{Non Vegetarian Foods (see for details, ref., [4])}

Among non vegetarian foods seafood and fish provide omega-3 rich fatty acids. These acids help in developing the brain and eyes of the fetus. Whereas, eggs are the ultimate health food, because they contain a little bit of almost every nutrient needed by pregnant woman. Eggs are a great source of choline. Beef, pork and chicken are excellent sources of high-quality protein. Furthermore, beef and pork are also rich in iron, choline and other B-vitamins - all of which are needed in higher amounts during pregnancy. As for as possible avoid processed meat, the preservative are harmful for the growing embryo.

\section{Constipation During Pregnancy}

Higher levels of progesterone during pregnancy causes the relaxation of body muscles (including intestinal), results into slower movements of the intestines. The digestion also becomes slower. In addition, the uterus increases in size, putting pressure on the rectum. Therefore, constipation is common disorder during pregnancy. The digestion also becomes slower [5]. These combined effects can leave pregnant women looking for relief of toilet problems. This can lead to constipation which is not a big issue; however, during pregnancy the number of solutions of this disorder also shrinks [6,7]. The safest remedy is to take a diet high in fiber that helps to prevent constipation. Dietary fibers also supply pregnant women with vitamins and antioxidants.

\section{Change in Microbiotic Population During Pregnancy}

By studying 16S rRNA gene amplicon sequencing and cultivation distinct microbial communities in cervical canal, uterus, fallopian tubes and peritoneal fluid, differing from that of the vagina were found. While the vagina is home for trillions of bacteria, the uterus and the fallopian tubes are generally believed to be sterile, which would require the cervix to be a perfect barrier in the cervix, however, change in mucins conformation due to $\mathrm{pH}$ variations during the menstrual cycle and pregnancy which can in theory allow passage of bacteria during certain conditions. The vaginal microbiota has previously been reported to vary between ethnic groups and the menstrual cycle variations in the composition of the vagino-uterine microbiota are associated with a number of natural and diseased physiological conditions important for women's health [8-10]. So far it is not very clear that this change in vagino-uterine microbiota is due to woman's physiological conditions only or food has some role in this process. However, in recent study it is shown that composition of gut microbiota changes in pregnant women, and the changed microbial environment needs changed diet to keep proper balance between beneficial and harmful bacteria.

\section{References}

1. Gude NM, Roberts CT, Kalionis B, RG King (2004) Growth and function of the normal human placenta. Thromb Res 114(5-6): 397-407.

2. Winterhager E, Gellhaus A (2017) Transplacental Nutrient Transport Mechanisms of Intrauterine Growth Restriction in Rodent Models and Humans. Front Physiol 8: 951.

3. Marangoni F, Cetin I, Verduci E, Canzone G, Giovannini M, et al. (2016) Maternal Diet and Nutrient Requirements in Pregnancy and Breastfeeding. An Italian Consensus Document. Nutrients 8(10): E629.

4. Gupta PD (2019) You are what Your Mother Ate: Role of Dietary Fibers Arch Reprod Med Sexual Health 2(1): 30-34.

5. Sawicka B, Gupta PD (2018) Importance of dietary fiber and starch in the prevention of selected civilization diseases: a review. J Cell \& Tissue Res 18(2): 6485-6489.

6. Johnson P, Mount K, Graziano S (2014) Functional bowel disorders in pregnancy: effect on quality of life, evaluation and management. Acta Obst Gyne (Scandinavica) 93(9): 874-879.

7. Eswaran S, Muir J, Chey WD (2013) Fiber and functional gastrointestinal disorders. Am J Gastroenterol 108(5): 718-727.

8. Sara M, Solveig E, Cunningham A, Dunlop AL, Corwin EJ, et al. ( 2017) The Maternal Gut Microbiome during Pregnancy. MCN Am J Matern Child Nurs 42(6): 310-317.

9. Pelzer E, Gomez-Arango LF, Barrett HL, DekkerNitert M (2017) Review: Maternal health and the placental microbiom. Placenta 54:30-37.

10. Sawicka B, KaidJohar SR, Sood PP, Gupta PD (2017) Imbalance of Gut Microbiota Induces Cancer: A Review. J Cell and Tissue Res 17(2): 6073-6084. 
(C) Commons Attribution 4.0 License
Your next submission with Juniper Publishers will reach you the below assets

- Quality Editorial service

- Swift Peer Review

- Reprints availability

- E-prints Service

- Manuscript Podcast for convenient understanding

- Global attainment for your research

- Manuscript accessibility in different formats ( Pdf, E-pub, Full Text, Audio)

- Unceasing customer service

Track the below URL for one-step submission https://juniperpublishers.com/online-submission.php 